\title{
Trivializing your library
}

\author{
By Bonnie Gratch \\ Coordinator of Library User Education \\ Bowling Green State University
}

\section{Library trivia contest questions in the dorm dining halls for BI promotion.}

erome Library, Bowling Green State University, Ohio, recently experimented with a different public relations technique for informing students about library resources and services. The idea was planned before the popularity of the game, "Trivial Pursuit," but as a result, the timing was ideal for such an activity.

The idea originated at a library user education meeting at which we were discussing various chanels of communication on campus to use for BI promotion. Sharon Rogers, our associate dean, suggested placing table tents with trivia questions from a variety of reference publications on the dorm dining room tables. Other campus organizations have used this technique to announce events and activities. Table tents are merely folded pieces of construction paper that stand up (like a tent) on a flat surface with two sides which display information. In this way, persons sitting across from each other at a table can each view a side of the table tent. We decided the idea held great promise, and we thought students would have fun matching their wits to the challenge of the questions-kind of like doing the puzzles on the back of cereal boxes.

The first step involved getting the questions. As user education coordinator, I put out a call to all librarians to submit trivia questions with answers, and sources that would be of interest to our students. In addition, library educational media students enrolled in a reference sources class submitted questions. Sample questions that were eventually used included: Where was the first beer brewed in America?, and Where was Gloria Steinem born?

After the questions were identified, the project was given to a public relations student intern, Marty Wisler, who worked with Sharon Rogers to plan the campaign. They designed the physical format of the table tents, the process of distribution, and the publicity for the student newspaper. The layout consisted of 10 questions on one side and information about new library services on the other side. The answers and the sources were printed on the inside of the table tents. To add a little spice to the project, they decided to have a contest at the end of the three-week period when the table tents would be distributed. The university bookstore even donated a $\$ 25$ gift certificate to the winner of the contest.

The PR intern took complete charge of having the table tents produced and distributed, as well as producing publicity. Each week of the three-week period, she replaced them with new ones of a different color and with different questions. She was told by the dining room staff that students really enjoyed reading them, and it was evident to her that they had been handled, since they were sometimes smeared with food splotches.

Even though the trivia contest was scheduled just before final exam week, there was still a fairly good response. Students picked up an entry form at the main reference desk. The form consisted of 20 questions and a list of reference titles from which the questions had been drawn. Only one person got 
all 20 correct, so the selection of the winner was not difficult.

The experience was definitely worthwhile and will be repeated earlier in the semester during the next academic year. In addition to presenting li- brary reference sources in a somewhat nontraditional way, one could also use this technique to publicize library services and user education activities.

\title{
ACRL President's report, 1983-84
}

\author{
By Joyce Ball \\ ACRL's 45th President
}

\section{ACRL's past year in perspective.}

D and research libraries more clearly realized that ibraries are a major component of the information economy. The use of information has become a survival skill for each and every individual in our society. As a strong and well-functioning professional association, ACRL has continued its long tradition of providing a means of enhancing library service to the academic research communities. Many ACRL members participated in regular, on-going activi-

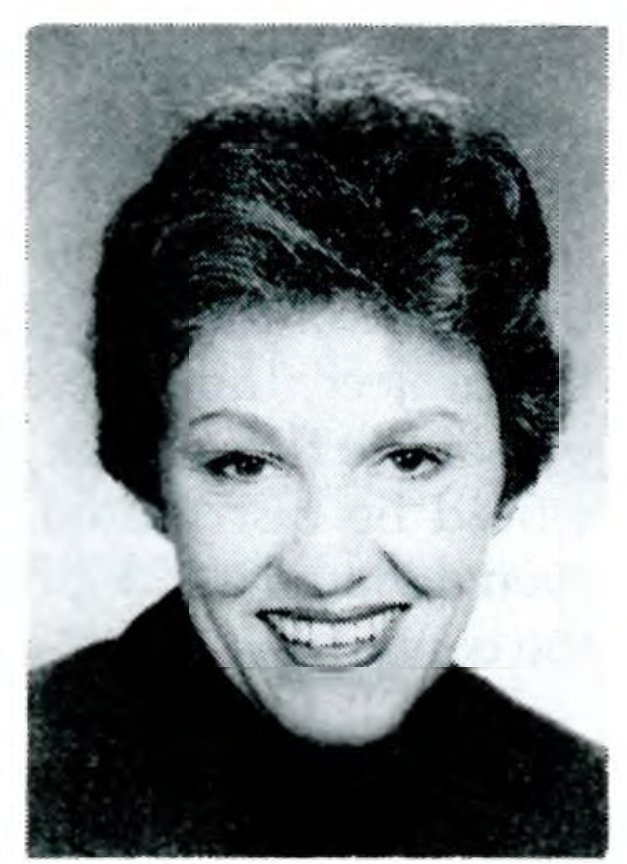

Joyce Ball ties: planning, budgeting, programming, continuing education, and publications. 1983-84, however, was a special year and the highlights of this year are presented below. A summary of the wide range of activities of the association and the details of annual operation appear in the ALA Yearbook.

In September 1984, Executive Director Julie Virgo and I were invited to represent ACRL on the Advisory Committee for Libraries and the Learn- ing Society. This project is being sponsored by the U.S. Department of Education to determine how libraries can effectively support the findings and recommendations of the National Commission on Excellence in Education. On the recommendation of the Advisory Committee, Richard Dougherty prepared a position paper for an invitational seminar which would frame a response for the academic library sector. The recommendations of twenty-five academic librarians were coordinated with those made by librarians from public libraries, school libraries and from professional schools. A report is to be published this summer. The ACRL President's Program scheduled for the Dallas conference will highlight activities within the Office of Education and the Center for Libraries and Education Improvement, Dougherty's paper, and a special report prepared by Executive Director Julie Virgo.

In April 1984, ACRL held its Third National Conference in Seattle. The Conference theme, Myths and Realities, was introduced by D. Kaye Gapen, dean, University of Alabama Library. Gapen's paper was one of almost fifty papers presented to the 1,220 librarians attending the conference. If the variety of topics, the level of attendance, the active participation of conference attendees, and the exhibition of new products by 